\title{
Roadworthiness Test For Traffic Safety
}

\author{
Case Study of Bastiong Highway of Ternate City \\ Nurwidyasari Usman ${ }^{1}$, Muhammad Rizal², Edward Rizky Ahadian ${ }^{3}$, Nani Nagu ${ }^{4}$ \\ Department of Civil Engineering \\ Universitas Khairun \\ Ternate-Indonesia \\ 2adams.rizal@yahoo.co.id
}

\begin{abstract}
Absrtact - Road growth must provide security and safety for road users. Article 23 of the Law of the Republic of Indonesia No.22 of 2009 states that the government as a road operator is obliged to provide a sense of security and safety for service users. The data analysis technique used in this project is qualitative analysis. The result is based on the attachment of three ministerial regulations for public works number 11 / PRT / M / 2010. Based on the technical feasibility test on the Bastiong highway in Ternate. The roadworthiness category is a conditional function worthy category $(L S)$ with several recommendations as technical improvements to realize a safe road. The growth of the number of vehicles towards the safety and safety of road users on the Bastiong highway has influence but does not have too significant influence, because according to observations in the field, getting fact that dense traffic density does not occur every hour, only in certain hours, for example at 7:30 a.m. in the morning where people began their activity of moving pass the Bastiong highway, then at 13.00 WIT which is the break time and at 17.00 WIT as time to go home.
\end{abstract}

Keywords: Worthy of Function, Road User, Road Operator

\section{INTRODUCTION}

Road growth must provide security and safety for road users. Article 23 of The Republic of Indonesia Law no. 22 of 2009 states that the government as a road operator is obliged to provide a sense of security and safety for service users. Likewise with article 30 of the law of The Republic of Indonesia no. 38 of 2004 and article 102 of the Republic of Indonesia Government regulation no. 34 of 2006 which states that the road must meet the requirements for functional feasibility. In addition to laws and government regulations concerning eligibility requirements from the road, the ministry of public works as one of the road organizers also issues a permen on procedures and eligibility requirements for road functions. As stated in minister of public works regulation no. $11 / \mathrm{prt} / \mathrm{m} / 2010$ concerning the procedures and requirements for the proper function of the road. Requirements for road function are needed to maximize the role of the road as a transportation infrastructure that will provide a sense of security and comfort for road users. The risk of accidents that often occur on the highway. the purpose of this study are 1) to find out the condition of the bastiong highway, whether it meets the technical requirements of feasibility to provide safety for its users or not. 2) to determine the effect of the growth in the number of vehicles on the safety and safety of road users.

\section{METHODOLOGY}

\section{A. Data collection steps}

The following data collection step in the field. Roadworthiness data based on PU No. 11 / PRT / M / 2010. In the data retrieval, the road function test first knows the meaning of function (LF), conditional function (LS). So that when conducting a survey based on the functional feasibility test format it is not wrong to determine. This survey aims to find out the conditions on the Bastiong highway are still having good function to provide safety to its users or not. This survey was carried out with the help of using 4 people, to record the measurement results based on the testing format, from the 4 people 2 measurement people 1 person to record and 1 person for documentation.

Research data:

1. Primary data

a) Vehicle ownership data can be obtained from Ternate City Samsat.

b) Accident number data of the city of South Ternate, was collected from Jasa Raharja, Ternate City

2. Secondary data

Secondary data was obtained from the research site, either from the village office or other agencies, namely population growth and traffic growth.

\section{B. Data analysis techniques}

In the completion of this final project, the settlement is to test and examine the extent of the hypothesis stated earlier, using the Minister of Public Works No.11 / PRT / M / 2010.

\section{RESULTS AND DISCUSSION}

\section{A. Results}

The data analysis technique that used in this project is qualitative analysis. The results obtained from the percentage of infrastructure conditions can be seen in the table below to determine the level of road infrastructure availability for traffic safety on Bastiong highway segments based on the attachment of three public works ministerial regulations number 11 / PRT / M / 2010

1. Results of Field Testing Geometric techniques 
a) The traffic lane The traffic lane in the study area is $3.62 \mathrm{~m}$ and it is included in the functional feasibility (LF) category

b) The shoulder of the road in the study location is still relatively good and there is a bad one because it has been damaged but the road shoulders that still meet the PTJ standard are $1 \mathrm{~m}$. For the shoulder of the road in the study area, it is included in the LF (Laik Function) category.2 Technical pavement structure

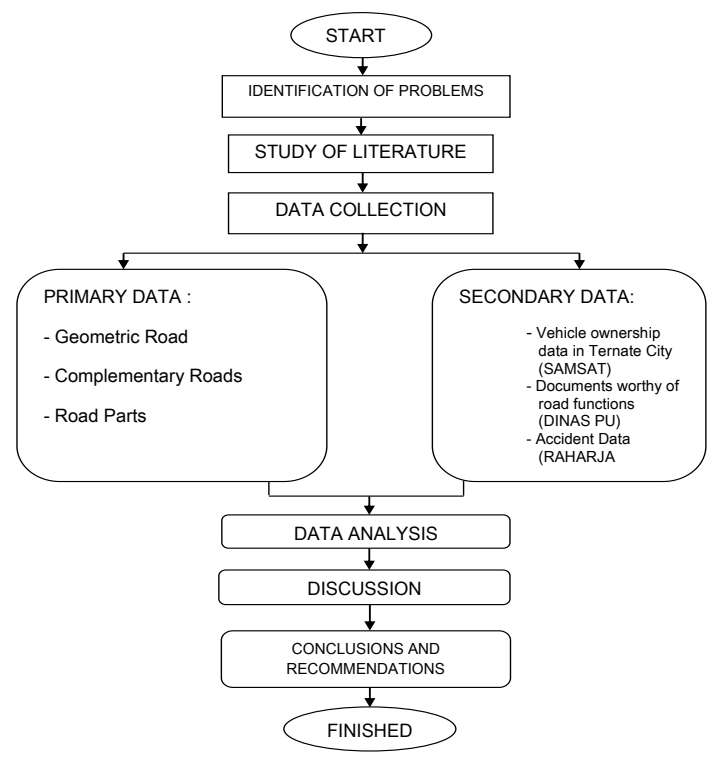

Fig. 1. Flow chart of the the research

2. The type of road pavement

a) In research location is a flexible pavement type (flexible pavement) for the current pavement condition is still good and is in the functional feasibility (LF) category.

b) Pavement conditions of Bastiong highway are currently in good condition and in accordance with the standards, for categories they are in the functional feasibility (LF) category.

3 Technical building of road complement

a) There is one bridge in the research location with good condition of the bridge both from the structure of the pavement and the backrest pole is still good, for the bridge in the LF category (Worthy of Function).

b) There is one culvert on the Bastiong highway exactly to the right of the sidewalk in front of the Bastiong mosque but the culvert works poorly because there is a lot of rubbish piled up in it so it does not function normally. For this category the culverts fall into the category of conditional function (LS).

c) Roadside channels on the Bastiong highway are categorized as functional (LF).

4 Technical Use of Road Parts a) In the standard for space the benefits of the road are $\geq 13$ meters while in the research location, the Bastiong highway is 7.5 meters, so this is in the category of eligible function (LS).

b) The standard for space owned by the road is $\geq 15$ meters while in the location is only 7.5 meters and this is included in the category of eligible function (LS).

c) On the Bastiong highway for the road supervision room is included in the category of conditional function (LS). Because it does not meet the standards of at least $15 \mathrm{~m}$.

5 Technical Equipment for Roads Directly Associated with Road Users

a) Road markings in the study area are still functioning, only need to be re-treated by the relevant parties because the paint color is almost faded, this is included in the category of conditional function (LS).

b) There are several road signs on the Bastiong highway and all are still in good condition and included in the functional feasibility (LF) category.

c) Sidewalks on the Bastiong highway are in line with the standard of 1.00 meters and this is included in the functional feasibility (LF) category for the test location 1 (first), while at the test locations both sidewalks have been damaged by tree roots and entered into categories (LS )

d) First testing, while the two sidewalks of testing locations have been damaged by tree roots and included in the category (LS).

e) Sidewalks on the Bastiong highway are in line with the standard of 1.00 meters and this is including functional feasibility (LF) category for the test location 1 (first), while at the test locations both sidewalks have been damaged by tree roots and entered into categories (LS )

f) Irrigation tools on Bastiong highway are included in the category of functional feasibility (LF), because their function is excelent.

The results of the analysis for the feasibility test of road function technically in realizing the safe road for the Bastiong highway in Ternate, are shown in table 4.1 for recommendations for improvement. 
TABLE I. Recommendations for the feasibility test results for road functions technically for highway sections Bastiong.

\begin{tabular}{|c|c|c|}
\hline Test Components & Recommendation & Documentation \\
\hline $\begin{array}{c}\text { Technical Function } \\
\text { Test } \\
\text { Geometric }\end{array}$ & $\begin{array}{l}\text { a. In general, the traffic lane } \\
\text { has met PTJ } \\
\text { requirements, namely> } \\
3.5 \text {. } \\
\text { b. Of the total road length } \\
\text { of } 6,442 \mathrm{~km} \text {, the road } \\
\text { should be } 1.0 \mathrm{~m} \text {. And } \\
\text { meet the minimum PTJ } \\
\text { standard of } 1.0 \mathrm{~m} \text {. } \\
\text { c. } \\
\text { It is necessary to control } \\
\text { the disruption of road } \\
\text { shoulder functions as } \\
\text { trash cans, tire patches } \\
\text { and taxibike bases. }\end{array}$ & \\
\hline $\begin{array}{c}\text { Technical Function } \\
\text { Test } \\
\text { Pavement Structure } \\
\text { Street }\end{array}$ & $\begin{array}{l}\text { a. Pavement using hotmix } \\
\text { asphalt, the pavement is } \\
\text { fairly flat and in the } \\
\text { center of the pavement } \\
\text { there is no cracking } \\
\text { symptoms, no grooves, } \\
\text { no waves. Roads can be } \\
\text { categorized as solid. } \\
\text { b. The condition of road } \\
\text { pavement is generally } \\
\text { good, but in some parts it } \\
\text { needs to be improved. }\end{array}$ & \\
\hline $\begin{array}{c}\text { Technical Function } \\
\text { Test } \\
\text { Building structure } \\
\text { Complement }\end{array}$ & $\begin{array}{l}\text { a. The bridge on the road is } \\
\text { in a stable condition and } \\
\text { functioning properly. } \\
\text { b. There are } 1 \text { (one) culverts } \\
\text { that cross the road. } \\
\text { Structure is still stable. } \\
\text { However, routine } \\
\text { cleaning is necessary to } \\
\text { expedite runoff. } \\
\text { c. Repair of the duct cover } \\
\text { that has been damaged. }\end{array}$ & \\
\hline
\end{tabular}




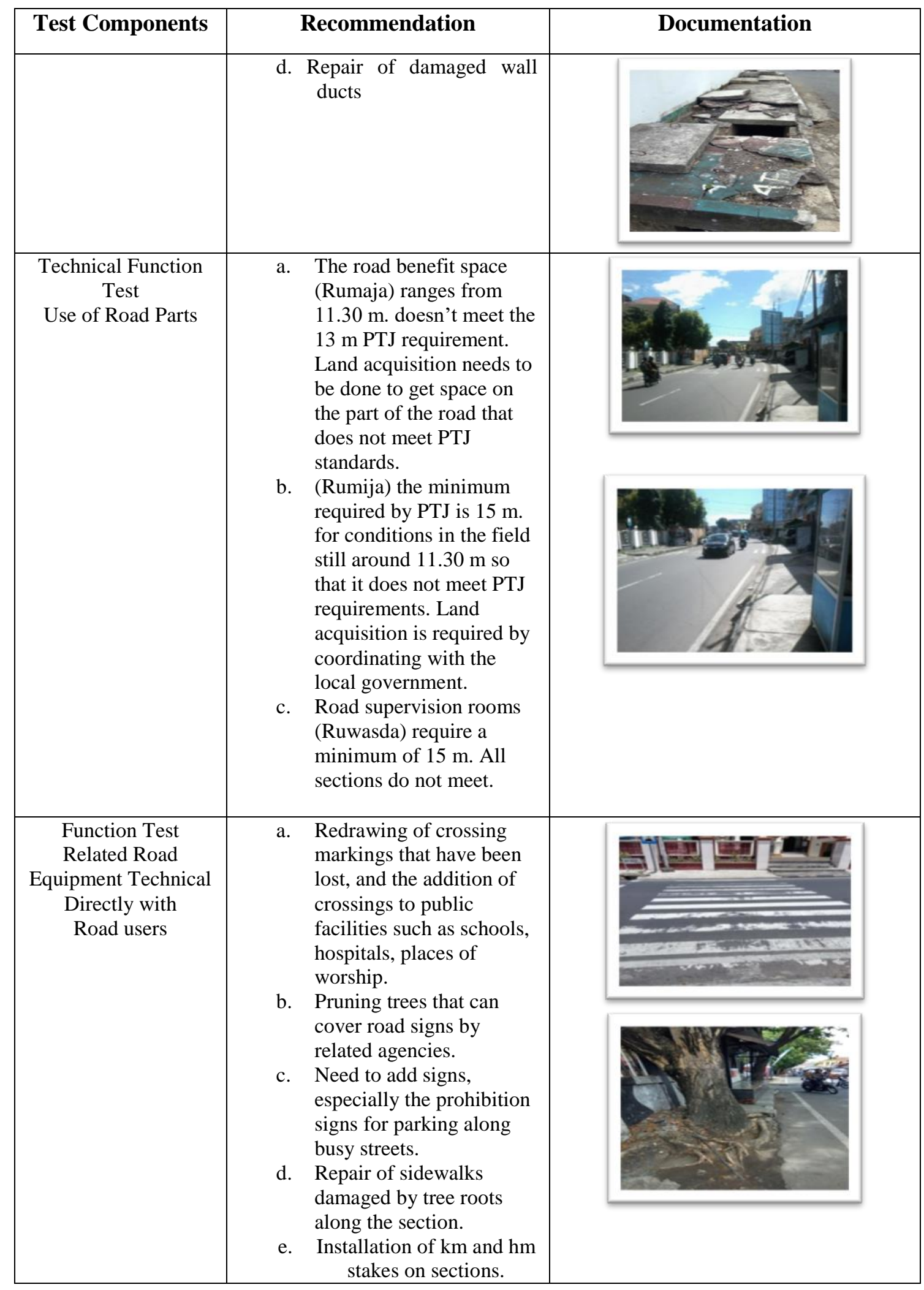


The results of the analysis for the feasibility test of road functions technically in realizing the safe road for the Bastiong highway are shown in table 4.1. Where the results of the technical function feasibility test based on attachment (three) on PU candy No. 11 / PRT / M / 2010 there were 84 components that were not tested from a total of 156 test items, because the Bastiong highway item was not include, because according to its function as a secondary arterial road and as a provider of road infrastructure is a small road, so the total items that can be tested are 22 items, of which 12 items meet the requirements and 10 others do not meet the criteria for road function.

\section{CONCLUSIONS AND RECOMMENDATIONS}

\section{A. Conclusions}

Based on the technical feasibility test on the Bastiong highway in Ternate, the roadworthiness category is a conditional function worthy category (LS) with several recommendations as technical improvements. The road worthy categories on the Bastiong highway in Ternate are as follows:

1. The condition of the road markings as an Eligible Conditional Function (LS), crossing place (zebra crossing) is categorized as conditional function because the paint has begun to fade and if it is drained for too long, zabra cross is not clearly visible for that it needs to be repainted by the local government.

2. Road signs as Function-Worthy (LF), the condition of signs in the study area is still very good condition, but need to add parking restrictions in some crowded places such as in the mosque depot, and on the other shoulder.

3. Sidewalks or pedestrian paths are categorized as conditional function (LS) because there are several places where sidewalks are not placed in the main function of pedestrian paths, but on the sidewalks are built ojeg bases and even there is also a trash can, this automatically diverts the main function of the sidewalk, therefore it is necessary to improve the actions of the parties concerned.

4. The roadside channel is categorized as functional (LF) because the standard for its size has fulfilled the requirements of 1.00 meters, but it needs repairs to the top cover of the channel and routine cleaning of the channel.

5. Road shoulders are categorized as conditional function (LS), not all road shoulders on the Bastiong highway are damaged, only on certain sections, namely depaN kantor pos, the shoulder of the road was damaged by the root of the tree planted on the side of the road.

\section{B. Recommendations}

Based on the previous conclusions, the author gives a suggestion.

1. Need an improvement or maintenance of road infrastructure and complementary road infrastructure, which is damaged, especially for additional boards covered with trees and road markings whose paint begins to fade.

2. It needs awareness for road users to be more obedient to the rules that have been set, because the cause of the biggest accident is the human factor in the form of a violation from the driver.

\section{References}

[1] Anonymus, Indonesian Road Capacity Manual, Ministry of Public Works, Director General of Bina Marga: Jakarta, 2010, downloaded from http://birohukum.pu.go.id.

[2] Directorate General of Highways, Procedures for Geometric Planning of Jalan Antar Kota, Jakarta: Ministry of Public Works, 1997.

[3] Directorate General of Highways, Study of Road Safety Needs in Indonesia Jakarta: Ministry of Public Works, 2006.

[4] M. N. Nasution, Menejemen Transportasi, Ghalia Indonesia: Jakarta, 2004.

[5] Minister of Public Works, Regulation Number 20/PRT/M/2010, 2010, downloaded from http://pelayanan.jakarta.go.id

[6] Transportation Minister, Regulation 2014 Number 34 concerning Road Markings, 2014, downloaded from http://hubdat.dephub.go.id.

[7] Minister of Transportation, Regulation 2014 Number 13 concerning traffic signs, 2014, downloaded from http://hubdat.dephub.go.id.

[8] S.P. Warpani, Traffic and Road Transportation Manager, Bandung: Penerbit ITB, 2002.

[9] Sudharmono, Indonesian Government Regulation on Roads, Jakarta: Ministry of State Secretary, 1985.

[10] J. Zachawerus, Appropriate Test of the Function of the Road in Realizing a Safe Way, 2016 [Sem. Nas. Tek. Sipil 2016, Univ. Muhammadiyah Surakarta]. 